\title{
Insight \\ Integrating Ethno-Ecological and Scientific Knowledge of Termites for Sustainable Termite Management and Human Welfare in Africa
}

\author{
Gudeta W. Sileshi ${ }^{1}$, Philip Nyeko ${ }^{2}$, Phillip O. Y. Nkunika ${ }^{3}$, Benjamin M. Sekematte ${ }^{4}$, \\ Festus K. Akinnifesi ${ }^{1}$, and Oluyede C. Ajayi ${ }^{1}$
}

\begin{abstract}
Despite their well-known role as pests, termites also provide essential ecosystem services. In this paper, we undertook a comprehensive review of studies on human-termite interactions and farmers' indigenous knowledge across Sub-Saharan Africa in an effort to build coherent principles for termite management. The review revealed that local communities have comprehensive indigenous knowledge of termite ecology and taxonomy, and apply various indigenous control practices. Many communities also have elaborate knowledge of the nutritional and medicinal value of termites and mushrooms associated with termite nests. Children and women also widely consume termite mound soil for nutritional or other benefits encouraged by indigenous belief systems. In addition, subsistence farmers use termites as indicators of soil fertility, and use termite mound soil in low-risk farming strategies for crop production. In the past, chemical control of termites has been initiated without empirical data on the termite species, their damage threshold, and the social, ecological, or economic risks and trade-offs of the control. This review has provided new insights into the intimate nature of human-termite interactions in Africa and the risks of chemical control of termites to human welfare and the environment. We recommend that management of termites in future should be built on farmers' indigenous knowledge and adequate understanding of the ecology of the local termite species.
\end{abstract}

Key Words: Agroforestry; biodiversity; geophagy; management; traditional ecological knowledge

\section{INTRODUCTION}

A distinct dichotomy exists between the pest management literature that depicts termites as "pests" and the ecological literature demonstrating their crucial role in ecosystems. There is no doubt that some species cause significant damage to crops, rangeland, trees, and structural timber. At the same time, they also play a beneficial role through promotion of essential ecological processes. The ongoing interest in sustainable agriculture and food security in Africa highlights the need for a more balanced approach to termite control and maintenance of their ecosystem services. To begin to address the mismatch between these two objectives, a holistic appraisal of the termite problem and opportunities for their sustainable management is needed. Sustainable termite management is defined here as one that ensures (1) control of the pest species without causing ecological damage and loss of the ecosystem services provided by termites, (2) conservation of the non-pest termite species, and (3) use of termites and associated resources without exhausting them. Management of risk and ensuring resilience are key concepts in sustainability, and these beg for a strategy that combines the skills and indigenous technical knowledge of farmers with modern scientific knowledge (Sileshi et al. 2008a).

Termites are a large and diverse group of insects consisting of over 2600 species worldwide. With over 660 species, Africa is by far the richest continent in termite diversity (Eggleton 2000). Most (ca. 85\%) of the known genera and those species that damage crops, trees, and rangeland belong to the family Termitidae. This family consists of four subfamilies: Macrotermitinae, Nasutitermitinae, Termitinae, and Apictotermitinae. Although the exact number of pest species is not known, it is estimated that less than $20 \%$ of members of the family Termitidae are serious pests (Pomeroy et al. 
1991, Mitchell 2002). Over 90\% of the termite damage in agriculture, forestry, and urban settings is attributed to members of the Macrotermitinae (Pomeroy et al. 1991, Mitchell 2002), which build the large mounds (hereafter called termitaria) that form the spectacular features of the African landscape (Glover 1967, Malaisse 1978). The reputation of termites as pests is also associated with the presence of termitaria in crop fields and near trees. Thus, most of the discussion in this paper focuses on the members of the Macrotermitinae.

The main genera in the subfamily Macrotermitinae are Odontotermes (79 species), Microtermes (33 species), Macrotermes (21 species), Ancistrotermes (nine species), Allodontermes (seven species), and Pseudacanthotermes (five species) (Pomeroy et al. 1991, Darlington et al. 2008). The taxonomy of Macrotermitinae is notoriously difficult, and many species are not easy to identify with certainty (Darlington et al. 2008). Unfortunately, current recommendations for termite control do not take into account this taxonomic difficulty.

Macrotermes, Odontotermes, and Microtermes species tolerate semi-arid and even arid areas (Eggleton 2000). Forty percent of Africa's population lives in arid, semi-arid, and dry subhumid areas (see map by D. Digout on the United Nations Environment Programme (UNEP) GRIDArendal website http://maps.grida.no/go/graphic/ar idity zones), and practices agro-pastoral production systems. In traditional agro-pastoral systems, when land productivity declines, the farmers shift to a new area. With the rapid increase in human population, the rate of conversion of natural habitat has increased and land degradation is taking place at a faster rate (United Nations University (UNU) 1998). Approximately $22 \%$ of vegetated land in Africa has been classified as degraded, and $66 \%$ of this is classified as moderately to severely degraded (UNU 1998). Most of these areas experience periodic droughts, and climate change has made them even more prone to frequent dry spells. Crops and trees are increasingly planted on marginal land, resulting in greater stress and vulnerability to termite attack (Glover 1967, Wood et al. 1980). In some places, such as the "Cattle Corridor" of Uganda, overstocking has led to depletion of forage to the extent that termites have to feed on whatever lies in their way (Sekamatte and Okwakol 2007, Tenywa 2008). As humans encroach into bushland, the conflict between humans and pest termites will increase.
It must be noted that the pest activity is a part and parcel of the termite's beneficial role in various ecosystems (Glover 1967, Black and Okwakol 1997). Macrotermitinae collect up to $60 \%$ of the grass, woody material, and annual leaf fall to construct the fungus gardens in their nests (Lepage et al. 1993). This translates to 1.5 tons of litter removal per hectare every year (Jones 1990, Lepage et al. 1993), which leads to a dramatic reduction in "fuel load" and fire intensity, while at the same time preserving nutrients in termitaria beyond the reach of fire (Lepage et al. 1993). By breaking down up to $100 \%$ of the litter fall and mineralization of up to $50 \%$ of the net primary production, termites influence ecosystem services such as nutrient cycling and biomass production (Jones 1990). From this viewpoint, termites are beneficial for the functioning of forest and savannah ecosystems. Termites also play a significant role in the availability of nutrients and water to crops and trees, and hence the productivity of agricultural ecosystems (Black and Okwakol 1997). Throughout the semi-arid regions of West Africa, crop-growth variability related to termite activity has been used by subsistence farmers in low-risk farming strategies for crop production (Mielke and Mielke 1982, Brouwer et al. 1993, Harris et al. 1994).

Therefore, agriculture holds the key to the management of termites and conservation of biodiversity as small-scale farmers are the ultimate managers and stewards of the land (Sileshi et al. 2008a). Resource-poor farmers look for practices that best fit their biophysical, economic, and sociocultural conditions. Ethno-ecology or traditional ecological knowledge (Berkes 2008) is particularly important for the formulation of sustainable termite management in Africa. Traditional ecological knowledge is defined as "a cumulative body of knowledge, practice and belief evolving by adaptive processes and handed down through generations by cultural transmission, about the relationship of living beings with one another and with their environment" (Berkes 2008). Engagement of researchers with local communities may thus help researchers to link their efforts to the local environmental and cultural context.

The objective of this paper is to bring together farmers' ethno-ecological knowledge and evidence from soil science and ecology in order to build more coherent principles for sustainable termite management. Toward that end, we undertook a 
comprehensive review of case studies on humantermite interactions from across Sub-Saharan Africa (Fig. 1) and, summarize the key findings in a comparative framework (indigenous vs. scientific) using the following specific themes: (1) farmers' ethno-ecological knowledge of termites and (2) termite management practices. Finally, we describe the potential impacts of termite management practices on the ecosystem services that termite species provide in the agro-pastoral systems of SubSaharan Africa.

\section{METHODS}

More than 10 studies related to farmers' ethnoecological knowledge of termites were found by searching the internet and databases, and checking the references of published studies across SubSaharan Africa. Emphasis was placed on eastern and southern Africa because this is the geographic area where the Macrotermitinae, which are the most serious pests in agriculture and forestry, reach their highest densities (Jones 1990). The bulk of the discussion is based on studies conducted in five districts of Malawi (Sileshi et al. 2008b), two districts of northwest Mozambique (Sileshi et al. 2008b), three districts of eastern Zambia (Sileshi et al. 2008b), six districts of southern Zambia (Nkunika 1998), Tororo district of Uganda (Nyeko and Olubayo 2005), and Machakos district of Kenya (Malaret and Ngoru, 1989). The specific sites (Fig. 1) are characterized by extreme variability of rainfall, drought, and dry spells. Drought is defined as absence of rainfall over an extended period of time, usually a season or more, whereas dry spell is a period of abnormally dry weather conditions less severe than those of a drought.

The data-collection methods employed in the specific study sites (Fig. 1) included community meetings, focus-group interviews, application of semi-structured questionnaires to farmers, and direct field observation by the authors. A participatory rural appraisal (PRA) was used in the study in eastern Uganda (Nyeko and Olubayo 2005). The farmers in Uganda gave information on (1) identity of the termite species, (2) abundance and distribution of termites, (3) termite damage to trees and crops, (4) relationship between termite damage and rainfall patterns, (5) priority termite species for control, (6) termites as a source of food, and (7) termite control practices. During community meetings and focus-group interviews in Malawi, Mozambique, and Zambia (Nkunika 1998, Sileshi et al. 2008b), farmers provided information on (1) cultivated plants attacked by termites, (2) stage of crop susceptible to attack, (3) time of termite attack, and (4) indigenous control practices. During group interviews in Kenya, farmers provided information on (1) local names and descriptions of termites, (2) soil and land-use preferences of termites, (3) cultivated and wild plants attacked by termites, (4) stage and condition of the plants when attacked, (5) termite-resistant or repellent plants, and (6) termite control practices (Malaret and Ngoru 1989).

Individual interviews designed to supplement results from community meetings were also conducted in eastern Zambia. In all study sites, the researchers made direct field observations, collected specimens to confirm termite identity or their damage, and obtained authoritative identification of the termite samples.

\section{SYNTHESIS}

\section{Farmers' Ethno-Ecological Knowledge}

Review of the specific studies and the general literature indicated that farmers have a rich knowledge of termite biology and the ecosystem services provided by termites. What follows is a brief summary of key findings using a comparative analysis of farmers' indigenous knowledge and scientific knowledge.

\section{Farmers' knowledge of termite taxonomy}

Local communities are able to identify the major genera and species using vernacular names (Table 1). For example, in Tororo district of Uganda, a total of 14 species were identified with distinct vernacular names (Nyeko and Olubayo 2005; Table 1). Similarly, $70 \%-100 \%$ of the farmers interviewed across five other districts of Uganda were able to identify various termites in their area (Sekamatte and Okwakol 2007). Farmers were also able to identify termites using vernacular names in Kenya (Malaret and Ngoru 1989; Table 1), Somalia (Glover 1967), Zambia, and Malawi (Nkunika 1998, Sileshi et al. 2008b; Tables 1, 2). Farmers' taxonomy also showed high internal consistency and closely corresponded to termite genera (Malaret and Ngoru 1989, Nyeko and Olubayo 2005). 
Fig. 1. The specific study sites and countries in Sub-Saharan Africa (in black outline) for which literature (L) was available for this synthesis. The specific sites are (1) Tororo district in eastern Uganda, (2) Machakos district in eastern Kenya, (3) Kasungu, (4) Mchinji, (4) Dedza, (5) Ntcheu, (6) Balaka, and (7) Zomba districts in Malawi, (8) Angonia and (9) Tsangano districts in northwest Mozambique, (10) Chipata and (11) Katete in eastern Zambia, (12) Mazabuka and Monze, (13) Gwembe and Choma, and (14) Kalomo and Livingstone districts in southern Zambia. The study sites were superimposed on the aridity map of Africa (UNEP/GRID-Arendal 2002).

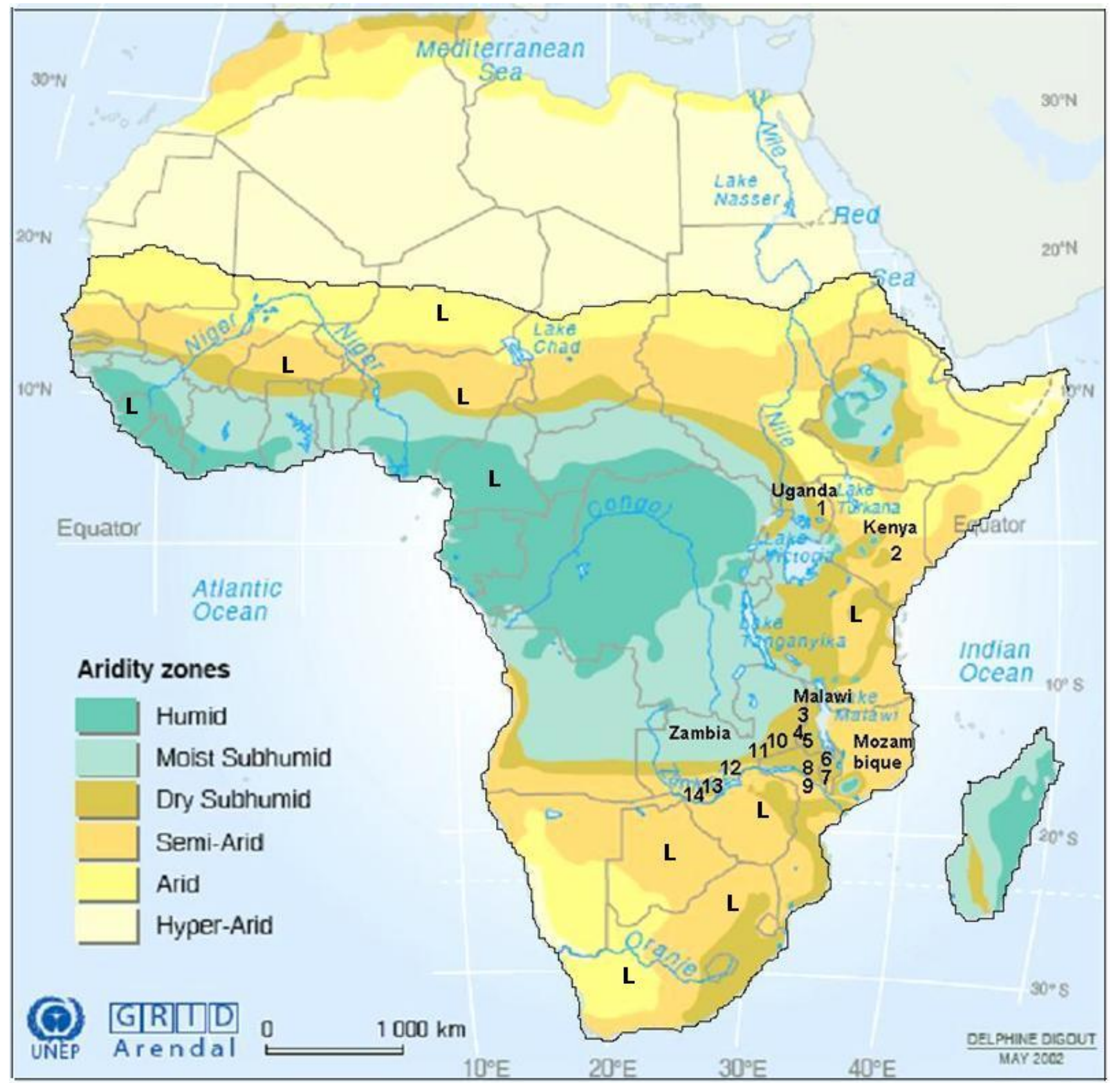


Table 1. List of termite genera and species, their corresponding vernacular names, indigenous knowledge of their pest status, and uses as sources of food and mushrooms in Zambia, Malawi, Uganda, and Kenya

\begin{tabular}{|c|c|c|c|c|c|c|}
\hline Country & District & Species name (local name) & Vernacular name & Pest & Edible & Mushroom \\
\hline \multirow[t]{13}{*}{ Zambia $^{\text {a }}$} & Kalomo & Macrotermes falciger & Machenya & Yes & Yes & Yes \\
\hline & Gwembe & & Muchenje, Chaca, Machenya & Yes & Yes & Yes \\
\hline & Mazabuka & & Muchenje, Makwakwasi & Yes & Yes & Yes \\
\hline & Monze & & Muchenje, Chisinza & Yes & Yes & Yes \\
\hline & Choma & & Simachenya, Machenya & Yes & Yes & Yes \\
\hline & Livingstone & & Machekenene, Mpango & Yes & Yes & Yes \\
\hline & Monze & Odontotermes spp. & Chuulu, Mumona & Yes & No & Yes \\
\hline & \multirow[t]{5}{*}{ All } & Allodontotermes spp. & Lumona, Mulyazi, Chimuma & Yes & No & No \\
\hline & & Microtermes spp. & Lumona, Mulyazi, Chimuma & Yes & No & No \\
\hline & & Amitermes truncatidens & Chuulu, Mumona & Yes & No & No \\
\hline & & Pseudacantthotermes sp. & Lumona, Mulyazi, Mulahi & Yes & Yes & Yes \\
\hline & & Trinervitermes rhodesiensis & Lumona, Mulyazi & No & No & No \\
\hline & Monze & Cubitermes tenuiceps & Kashimbwa, Tuumbusu & No & No & No \\
\hline \multirow[t]{4}{*}{ Zambia $^{\mathrm{b}}$} & Chipata & Macrotermes subhyalinus & Kalanzi & Yes & Yes & Yes \\
\hline & Chipata & M. falciger & Magenge & Yes & Yes & Yes \\
\hline & \multirow[t]{2}{*}{ Chipata } & Odontotermes spp. & Gegedule & Yes & Yes & ND \\
\hline & & Microtermes spp. & Kauni & Yes & ND & ND \\
\hline Malawi ${ }^{b}$ & Balaka & M. michaelseni & Madulila & Yes & Yes & Yes \\
\hline \multirow[t]{8}{*}{ Uganda $^{c}$} & \multirow[t]{8}{*}{ Tororo } & Macrotermes subhyalinus & Agoro & Yes & Yes & Yes \\
\hline & & Macrotermes bellicosus & Ripo & Yes & Yes & No \\
\hline & & Cubitermes ugandensis & Aming & No & No & No \\
\hline & & Basidentitermes sp. & Aming & No & No & No \\
\hline & & Microcerotermes sp. & Kithea & No & No & No \\
\hline & & Odontotermes kibarensis & Magrere & Yes & Yes & Yes \\
\hline & & Odontotermes (?latricius & Singiri & No & Yes & Yes \\
\hline & & Odontotermes sp. 1 & Ogwee & Yes & Yes & Yes \\
\hline
\end{tabular}




\begin{tabular}{llllll}
\hline & Odontotermes sp. 2 & Mbala & No & Yes & No \\
& Pseudacanthotermes spriniger & Miyal & Yes & Yes & Yes \\
& Pseudacanthotermes militaris & Sisi & Yes & Yes & Yes \\
& Pseudacanthotermes sp. & Wambwe & Yes & Yes & Yes \\
& Amitermes (? Truncatidens & Rudho & Yes & No & No \\
& Trinervitermes oeconomus & Thuk & No & No & No \\
Kenya $^{d}$ Machakos & Macrotermes spp. & Nthwa, Mungasa & Yes & ND & ND \\
& Odontotermes spp. & Mbaa, Mbaawa & Yes & ND & ND \\
& Microcerotermes spp. & Mungumi, Kathoa & Yes & ND & ND \\
& Pseudacntotermes spp. & Ngai, Kikai & Yes & ND & ND \\
& Allodontotermes spp. & Ndulamatu, Mungasa & Yes & ND & ND \\
& Cubitermes spp. & Kikii & No & ND & ND \\
\hline
\end{tabular}

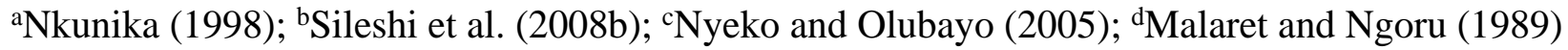

? Species name uncertain

No $=$ termite does not produce mushrooms or the mushroom produced is not edible

$\mathrm{ND}=$ not determined

Farmers' knowledge of termite abundance and distribution

Farmers have also good understanding of the abundance and distribution of termites in their area. For example, most farmers in Tororo district rated Macrotermes bellicosus and M. subhyallinus as the most abundant (Nyeko and Olubayo 2005). This is in agreement with scientific studies in Uganda (Pomeroy 1978). However, farmers' rating of $M$. bellicosus as more abundant in the upland and $M$. subhyallinus more abundant in the lower altitudes disagrees with Pomeroy (1978), who states that the two species have similar distributions. Farmers in Machakos district of Kenya associated Macrotermes and Odontotermes with farmland more than bushland. They could also identify the humus feeders from those that attack crops or trees (Malaret and Ngoru 1989).

\section{Farmers' perception of termites as pests}

Studies evaluating farmers' perceptions of termites (Nkunika 1998, Nyeko and Olubayo 2005,
Sekamatte and Okwakol 2007, Sileshi et al. 2008b) have demonstrated that farmers have good knowledge of those species that are pests (Tables 1 , 2). In Tororo district of Uganda, farmers identified eight pest species (Table 1). However, they rated $M$. bellicosus and $M$. subhyallinus as more serious than the other species (Nyeko and Olubayo 2005). Although Pseudacanthotermes spriniger was reported to damage some crops, farmers perceived it as a minor pest that does not merit control (Nyeko and Olubayo 2005). Out of the six genera identified by farmers in southern Zambia, M. falciger was at the top of the pest list (Nkunika 1998). In eastern Zambia, farmers ascribed most of the crop damage to $M$. falciger and $M$. subhyallinus (Table 2). Microtermes species considered major pests in Africa (Wood et al. 1980) were not rated as serious pests by most farmers (Malaret and Ngoru 1989, Nyeko and Olubayo 2005, Sileshi et al. 2008b). This is probably because Microtermes species do not build termitaria. Damage to plants by Microtermes, Allodontermes, and Ancistrotermes spp. is often internal or subterranean. This probably makes these species less apparent to farmers. 
Table 2. Percentage of respondents identifying termites that attack crop plants by local names in eastern Zambia (source: Sileshi, unpublished data)

\begin{tabular}{llllllllll}
\hline \hline & $\begin{array}{l}\text { Number of } \\
\text { respondents }\end{array}$ & \multicolumn{2}{l}{ Percentage of cases where the termite's local name was mentioned or unknown } \\
Crop & & Magenge & Kalanzi & Muswe & Chiswe & Gegedule & Mphusi & Kauni & Unknown \\
\hline Maize & $87(100)$ & 45.3 & 30.5 & 11.6 & 5.2 & 1.1 & 0 & 1.1 & 5.3 \\
Groundnut & $78(89.7)$ & 37.8 & 34.6 & 12.7 & 5.1 & 1.2 & 1.3 & 1.3 & 6.1 \\
Sunflower & $24(27.6)$ & 45.8 & 33.3 & 12.5 & 8.3 & 0 & 0 & 0 & 0 \\
Cotton & $23(26.4)$ & 47.8 & 17.4 & 13.0 & 8.7 & 0 & 4.4 & 0 & 8.7 \\
Soybean & $19(21.8)$ & 68.4 & 21.1 & 5.3 & 0 & 0 & 0 & 0 & 5.3 \\
Beans & $17(19.5)$ & 41.2 & 35.3 & 11.8 & 0 & 5.9 & 0 & 0 & 5.9 \\
Cassava & $12(13.8)$ & 58.3 & 25.0 & 0 & 8.3 & 0 & 0 & 0 & 8.3 \\
Cowpea & $3(3.4)$ & 33.4 & 66.6 & 0 & 0 & 0 & 0 & 0 & 0.0 \\
\hline
\end{tabular}

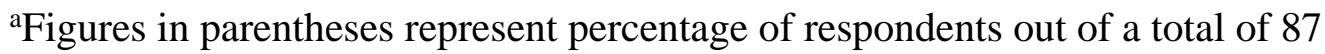

\section{Farmers' perception of susceptibility of plants to termites}

Farmers were also able to identify which crop or tree species were susceptible to termite attack and which were resistant. Farmers rated maize (Zea mays L.), groundnut (Arachis hypogaea L.), and sugarcane (Saccharum spp.) as highly susceptible to termite damage in Uganda (Nyeko and Olubayo 2005), Kenya (Malaret and Ngoru 1989), and Zambia (Sileshi et al. 2008b). Maize and groundnut were particularly rated as highly susceptible by most respondents (>90\%) in eastern Zambia (Table 3). The farmers' assessment is in agreement with the entomological studies conducted elsewhere in Africa (e.g., Wood et al. 1980). In Machakos district of Kenya, farmers identified 24 species of trees and shrubs as resistant to termites (Malaret and Ngoru 1989). Ugandan farmers identified Eucalyptus species and Grevillea robusta as particularly highly susceptible to $M$. bellicosus and M. subhyallinus (Nyeko and Olubayo 2005). The more serious damage on the exotic crops (e.g., maize and groundnuts) and trees (e.g., Eucalyptus and
Grevillea) is probably because these species lack resistance to African termites (Logan et al. 1990, Mielke and Mielke 1982). Indigenous African crops and trees are expected to be resistant to these termites with which they have co-evolved. Contrary to scientific reports that termites rarely attack vigorously growing plants (Wood et al. 1980), some farmers stated that termites attack both healthy and unhealthy plants (Malaret and Ngoru 1989). This does not necessarily mean that farmers are incorrect in their assessment. Rather it indicates that there are areas where local knowledge differs from scientific studies.

Most farmers in eastern Zambia believe that crops become susceptible to termite attack at maturity (Table 3), and this agrees with the literature (Wood et al. 1980). According to these farmers, termite damage to crops and trees is more severe during dry spells or drought periods. Similarly, Ugandan and Kenyan farmers considered termite damage to be more severe in the dry months compared with the wet months (Malaret and Ngoru 1989, Nyeko and Olubayo 2005). Damage by termites is greater 
Table 3. Farmers' perception of susceptibility of crops to termite damage and time of crop damage in eastern Zambia (source: Sileshi, unpublished data)

\begin{tabular}{lllllll}
\hline \hline & $\begin{array}{l}\text { Rating of crop as } \\
\text { susceptible }(\%)^{\mathrm{a}}\end{array}$ & \multicolumn{5}{c}{ Rating of time of crop damage (\% of respondents $\left.{ }^{\mathrm{b}}\right)$} \\
Crop & & Continuous & $\begin{array}{l}\text { Dry spell } \\
\text { (rainy season) }\end{array}$ & $\begin{array}{l}\text { Dry } \\
\text { season }\end{array}$ & $\begin{array}{l}\text { Do not } \\
\text { known }\end{array}$ & Period of highest damage \\
\hline Maize & $100.0(87)$ & 2.1 & 88.4 & 8.4 & 1.1 & Flowering onward $(83.1 \%)$ \\
Groundnut & $89.7(78)$ & 0 & 84.6 & 12.8 & 2.6 & Flowering onward $(82.1 \%)$ \\
Sunflower & $27.6(24)$ & 0 & 70.8 & 29.2 & 0 & Flowering onward $(85.0 \%)$ \\
Cotton & $26.4(23)$ & 4.4 & 95.6 & 0 & 0 & Flowering onward $(69.5 \%)$ \\
Soybean & $21.8(19)$ & 10.5 & 73.7 & 15.8 & 0 & Flowering onward $(73.7 \%)$ \\
Beans & $19.5(17)$ & 17.7 & 76.5 & 0 & 5.9 & Flowering onward $(65.7 \%)$ \\
Cassava & $13.8(12)$ & 33.3 & 33.3 & 33.3 & 0 & Maturity (41.7\%) \\
Sugar cane & $4.6(4)$ & 25.0 & 0 & 75.0 & 0 & Throughout the year $(100 \%)$ \\
\hline
\end{tabular}

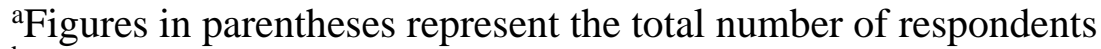

${ }^{\mathrm{b}}$ The $\%$ was calculated using the respective number of respondents for each crop (figures in parentheses in column 2)

during dry periods or droughts than periods of regular rainfall (Logan et al. 1990, Black and Okwakol 1997, Sileshi et al. 2005). The increases in termite damage could also be associated with climate change-induced drought. In recent decades, drought linked to El Niño episodes has become more intense and widespread in southern Africa (Fauchereau et al. 2003).

Farmers in Uganda and Zambia also mentioned that termite problems are more serious now than in the past (Sekamatte and Okwakol 2007, Sileshi et al. 2008b, Tenywa 2008). In a recent survey of eastern Uganda, elders linked the increasing termite problem and low abundance of predatory ant species to aerial sprays intended to control tsetse flies (Glossina sp.) during the 1960s and 1970s (Sekamatte and Okwakol 2007). Termite damage on trees and crops could have increased as a result of the depletion of the usual termite food due to deforestation and overgrazing (Tenywa 2008).
Deforestation may also have resulted in loss of the natural enemies of termites such as the aardvark (Orycteropusafer), pangolin (Manis spp.), aardwolf (Proteles cristatus), and hedgehog tenrec (Echinops tefairi) (Pomeroy et al. 1991, Peveling et al. 2003). Habitat loss has led to the disappearance of the aardvark in countries such as Ethiopia (Jiru 2006). Continuous cultivation and overstocking reduce the diversity of termites (Glover 1967, Black and Okwakol 1997, Eggleton et al. 2002) followed by outbreak of those species that tolerate disturbances (Wood et al. 1980).

\section{Farmers' knowledge of the role of termites in human nutrition and health}

The literature reviewed indicated that farmers have extensive knowledge of the value of termites in human nutrition. The alates, queen, and soldiers of some species in the subfamily Macrotermitinae are eaten across most of Africa. Local people easily tell 
the edible termites from those unsuitable for consumption (Table 1). Out of the 14 species identified in Tororo district, only 10 were consumed. Some species were not eaten due to various reasons (Nyeko and Olubayo 2005).

Some communities also have an intimate knowledge of the association between termites and edible mushrooms (Oso 1975, Yongabi et al. 2004, Nyeko and Olubayo 2005, Kabasa et al. 2006). The Macrotermitinae cultivate edible mushrooms in the genus Termitomyces in the termitaria. Each year, these fungi produce a crop of large mushrooms, which are highly prized by people as a delicacy. According to the Guinness Book of Records, T. titanicus, which grows on termitaria, is the world's largest and one of the tastiest mushrooms. Communities in Uganda and Nigeria associated specific mushrooms with certain termite species and identified each Termitomyces species by local name (Oso 1975, Nyeko and Olubayo 2005). Many communities in Africa have elaborate indigenous knowledge of the nutritional and medicinal values of these mushrooms (Oso 1975, Yongabi et al. 2004, Nyeko and Olubayo 2005, Kabasa et al. 2006). According to an indigenous knowledge survey in Uganda, $45 \%$ of the respondents consumed $T$. microcarpus for its medicinal value, whereas 5\% consumed it just as food. Chemical analyses (Kabasa et al. 2006, Opige et al. 2006) demonstrate that Termitomyces species provide a low-fat, highfiber diet rich in protein, minerals $(\mathrm{Ca}, \mathrm{P}, \mathrm{K})$, and vitamins. In Cameroon, T. titanicus is dried and mixed with pastry for the consumption of underweight children (Yongabi et al. 2004). Termitomyces species are also used in the treatment of various diseases (Kabasa et al. 2006).

Termites also contribute to human nutrition and health through the deliberate ingestion of soil, a phenomenon called geophagy (Hunter 1973). Geophagy has been practiced by humans since antiquity and on almost every continent (Hunter 1973, Rowland 2002). Termitaria are the major sources of the soil consumed by women and children in Kenya (Geissler 2000, Luoba et al. 2004), Tanzania (Knudsen 2002), Zambia, Zimbabwe (Nchito et al. 2004), and South Africa (Saathoff et al. 2002). In many communities, geophagy is firmly grounded in indigenous belief systems (Geissler 2000, Knudsen 2002). In the cosmology of the Luo (a tribe in eastern Kenya) and Chagga (a tribe in northern Tanzania), termitaria symbolize sexuality and the feminine power of procreation, thus ingesting soil is good for the blood and for fertility of the woman (Geissler 2000, Knudsen 2002). Similarly, in cosmology of the San people in southern Africa, termitaria symbolize a spirit world that has unparalleled transformative and generative powers (Mguni 2006). Consumption of soil from termitaria is common among the nutritionally vulnerable populations, especially children and pregnant and lactating women (Wiley and Katz 1998). In a study involving 827 women in Bondo district of Western Kenya, 46\% reported geophagy during pregnancy and lactation (Luoba et al. 2004). Among children aged 5-18 in Western Kenya and Zambia, 73\%-74\% had ingested soil (Geissler 2000, Nchito et al. 2004). Consumption of soil was reported more often in girls $(53 \%-80 \%)$ than in boys $(39 \%-68 \%)$ in Zambia (Nchito et al. 2004) and South Africa (Saathoff et al. 2002). Among the positive health benefits of geophagy during pregnancy are improved maternal calcium status, improved foetal skeletal formation and birth weight, reduction in pregnancy-induced hypertension, and decreased risk of embryonic exposure to teratogens and loss of nutrients through emesis (Wiley and Katz 1998). Another adaptive function of consuming termite soil is the ability of clays to adsorb toxins from plants eaten by humans. Soil from termitaria is high in kaolinic clays, the same base used in Kaopectate, which is prescribed for stomach upset. This indigenous knowledge, therefore, has significant implications for adaptation to many of the toxins in plants eaten by people (Rowland 2002).

Farmers' knowledge of the role of termites in soil fertility

Subsistence farmers largely base their nutrientmanagement strategies on their perception of niche fertility (Brouwer et al. 1993, Adamou et al. 2007, Chikuvire et al. 2007). Within-field variability of soil properties creates niches that farmers perceive as essential to their farming (Brouwer et al. 1993). Termites, specifically the Macrotermitinae, create such niches and in most cases help farmers to reduce risks of crop failure (Mielke and Mielke 1982, Brouwer et al. 1993, Harris et al. 1994). Thus, farmers use termites as biological indicators of soil fertility status. Traditional soil classification is also based on termite presence or absence among some communities (Bellon et al. 1999, Ettema 1994, Adamou et al. 2007). Therefore, termites are an important element in traditional land-management practices in the Sahel (Mando et al. 1999), East 
Africa, and southern Africa (Mielke and Mielke 1982, Nyamapfene 1986). Subsistence farmers across Sub-Saharan Africa also encourage termite activity in their crop fields. For example, farmers in Burkina Faso bury manure in holes near newly planted millet in the belief that termites attracted to the manure will improve water availability to the crop (Logan 1992). Quantitative studies in Burkina Faso have demonstrated that this practice increases infiltration rates (Mando et al. 1999). Studies elsewhere also have demonstrated positive impact of termites on soil properties and water dynamics (Chikuvire et al. 2007).

Farmers' use of termite-modified soil in crop production has been documented in Uganda (Okwakol and Sekamatte 2007), Zambia (Siame 2005), Zimbabwe (Bellon et al. 1999, Nyamapfene 1986), Niger (Brouwer et al. 1993), and Sierra Leone (Ettema 1994). Farmers either plant specific crops on termitaria (Fig. 2) or spread soil from termitaria in their fields (Nyamapfene 1986, Logan 1992). A typical example of cropping around termitaria is the chitemene agriculture in southwestern Tanzania (Mielke and Mielke 1982). In Malawi, farmers plant various crops including bananas (Musa spp.) around termite mounds (Fig. 2). Ugandan farmers plant pumpkins (Cucurbita spp.), tomatoes (Solanum spp.), onions (Allium spp.), and maize adjacent to termitaria (Okwakol and Sekamatte 2007). In Zimbabwe, crops such as okra (Abelmoschus esculentus), pumpkins, sweet sorghum (Sorghum spp.), and late-season maize, which require good water and nutrient supply, are grown almost exclusively on termitaria (Nyamapfene 1986). In Niger, farmers preferentially plant sorghum on termitaria (Brouwer et al. 1993). In some areas, farmers break termitaria and spread the soil in their field. For example, in southern Zambia, farmers remove portions of the mound, making sure that they leave the base intact so that the colony is not destroyed. This soil is then transported to the field and worked into the top soil before the rains begin. In areas where conservation farming is practiced, soil from termite mounds is placed into planting basins (Siame 2005). In South Africa, circular patches of exceptionally well-grown sugarcane, known as "isiduli", are a common feature of sandy sugarcane fields. These correspond to mounds of $M$. natalensis leveled by ploughing (Cadet et al. 2004). Similarly, in Zimbabwe, farmers widely use soil from termitaria to improve soil fertility (Bellon et al. 1999, Nyamapfene 1986).
These farmers' practices have been a subject of studies, and scientific explanations do exist for most of them (Watson 1977, Nyamapfene 1986). For example, detailed studies show that cane yield is five times greater using the "isiduli" than elsewhere in the field (Cadet et al. 2004). Similarly, plant biomass and grass growth were significantly higher around termitaria compared with the open veld in the Eastern Cape (Steinke and Nell 1989). The increased growth of grass surrounding termitaria was due largely to accumulation of runoff water at the base. Not only could this lead to increased productivity during dry years, but it could also make it possible for plants to survive intense drought (Steinke and Nell 1989). The mineral content of termitaria and the adjacent soils has also been carefully measured by several researchers (Watson 1977, Steinke and Nell 1989, Holt and Lepage 2000, Cadet et al. 2004, Masanori and Tooru 2004, Brossard et al. 2007, Chikuvire et al. 2007). Most research shows that termitaria contain significantly higher concentrations of total nitrogen (N) and exchangeable cations than the surrounding area (Watson 1977, Steinke and Nell 1989, Jones 1990, Holt and Lepage 2000, Chikuvire et al. 2007). In tropical wet-dry climates, downslope erosion could enhance the soil fertility around termitaria compared with leached soils away from it (Malaisse 1978). In addition, soil from termitaria has other positive effects on crops such as suppression of weeds. For example, Cubitermes soil was found to suppress Striga infestation on sorghum effectively in Burkina Faso (Andrianjaka et al. 2007).

Although scientists believe that soil from termitaria may provide an alternative to chemical fertilizers, some farmers have resisted leveling termitaria (Logan et al. 1990). Scientists have expressed concern about why farmers do not level termitaria in order to make full use of the land and to facilitate mechanized tillage operations (Nyamapfene 1986). Such concerns ignore the spiritual (Geissler 2000, Copeland 2007) and economic values (Nkunika 1998) that farmers attach to termitaria. The recommendation of scientists also ignores the fact leveling termitaria is not sustainable in the long term. According to Brossard et al. (2007), excessive use of termitaria soil can affect termite populations besides mining nutrients. 
Fig. 2. Farmers' practice of planting crops around termitaria. This farmer in Zomba district of southern Malawi has planted banana and pigeon pea on an Odentotermes mound.

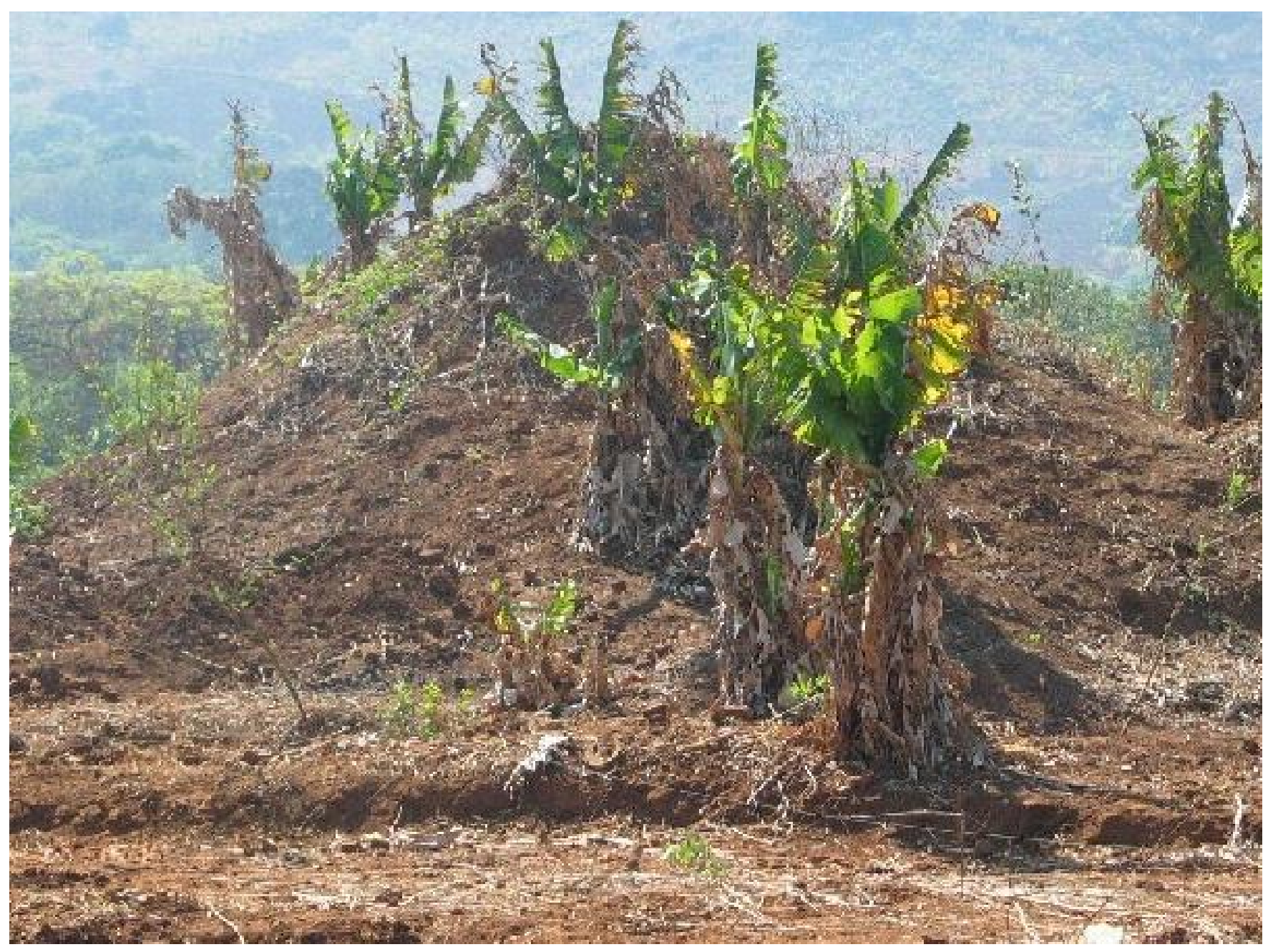

\section{Farmers' Termite Management Practices}

Although extension programs encourage the use of pesticides, most farmers in the study sites relied on indigenous control practices (Table 4). Although some of these are parts of good agricultural practices, the lack of critical scientific evaluation has limited their wider use. Here, we will briefly discuss the most common farmers' practices.

\section{Destruction of termitaria and the colony}

Farmers in the study sites mentioned different methods of destroying the colony (Table 4). These included digging the nest and removing the queen; burning wood, grass, or cow dung; pouring hot water, insecticides, rodenticides, or paraffin; and flooding the nest with rainwater to kill the colony (Malaret and Ngoru 1989, Nyeko and Olubayo 2005). Although destruction of the colony has been advocated by researchers (Logan et al. 1990), success has been limited because of various constraints including labor requirements and lack of knowledge about termite biology. This practice is directed toward mature colonies of the moundbuilding species, and species that do not build mounds (e.g., many Odontotermes and Microtermes spp.) are often overlooked. Those species that build 
Table 4. Farmers' indigenous termite management practices in Ethiopia, Kenya, Uganda, Malawi, and Zambia

\begin{tabular}{|c|c|c|c|}
\hline Control practices & Districts & $\begin{array}{l}\text { Country (part of } \\
\text { country) }\end{array}$ & References \\
\hline \multirow[t]{5}{*}{ Destruction of mound and colony } & Balaka & Malawi (southern) & Sileshi et al. (2008) \\
\hline & Katete, Chipata & Zambia (eastern) & Sileshi et al. (2008) \\
\hline & Tororo & Uganda (eastern) & Nyeko and Olubayo (2005) \\
\hline & Machakos & Kenya (eastern) & Malaret and Ngoru (1989) \\
\hline & S Gonder & Ethiopia (northern) & Jiru (2006) \\
\hline \multirow[t]{4}{*}{ Plant Euphorbia tirucali in field } & Balaka & Malawi (southern) & Sileshi et al. (2008) \\
\hline & Tsangano & $\begin{array}{l}\text { Mozambique } \\
\text { (northwest) }\end{array}$ & Sileshi et al. (2008) \\
\hline & Chipata, Katete & Zambia (eastern) & Sileshi et al. (2008) \\
\hline & Kalomo, Choma, Monze & Zambia (southern) & Nkunika (1998) \\
\hline \multirow[t]{2}{*}{ Apply Bobgunnia madagascarensis } & Chipata, Katete & Zambia (eastern) & Sileshi et al. (2008) \\
\hline & $\begin{array}{l}\text { Kalomo, Choma, Gwembe, } \\
\text { Monze, Livingstone }\end{array}$ & Zambia (southern) & Nkunika (1998) \\
\hline Spray Tephrosia extract & Chipata & Zambia (eastern) & Sileshi et al. (2008) \\
\hline \multirow[t]{4}{*}{ Apply wood ash } & Chipata, Katete & Zambia (eastern) & Sileshi et al. (2008) \\
\hline & $\begin{array}{l}\text { Kalomo, Gwembe, Monze, } \\
\text { Mazabuka, Livingstone }\end{array}$ & Zambia (southern) & Nkunika (1998) \\
\hline & Machakos & Kenya (eastern) & Malaret and Ngoru (1989) \\
\hline & Tororo & Uganda (eastern) & Nyeko and Olubayo (2005) \\
\hline \multirow[t]{2}{*}{ Avoid earthing up (banking) } & Chiosha & Malawi (central) & Sileshi et al. (2008) \\
\hline & Chipata & Zambia (eastern) & Sileshi et al. (2008) \\
\hline Minimum weeding & Chipata & Zambia (eastern) & Sileshi et al. (2008) \\
\hline \multirow[t]{2}{*}{ Clean weeding } & Chipata & Zambia (eastern) & Sileshi et al. (2008) \\
\hline & Machakos & Kenya (eastern) & Malaret and Ngoru (1989) \\
\hline \multirow[t]{2}{*}{ Apply pork, meat, fat to attract ants } & Mapanje & $\begin{array}{l}\text { Mozambique } \\
\text { (northwest) }\end{array}$ & Sileshi et al. (2008) \\
\hline & Machakos & Kenya (eastern) & Malaret and Ngoru (1989) \\
\hline \multirow[t]{2}{*}{ Apply cow dung or urine } & Monze & Zambia (southern) & Nkunika (1998) \\
\hline & Machakos & Kenya (eastern) & Malaret and Ngoru (1989) \\
\hline
\end{tabular}


mounds are subterranean for the first few years. Even if mature colonies are killed, the immature colonies could spread to take over the area (Logan et al. 1990). In addition, many farmers resist destroying the mounds (Nyamapfene 1986, Nkunika 1998) even when they are live or very easy to flatten (see Fig. 3). Mound destruction may not be acceptable, probably because termitaria are sacred places among many communities in Africa (Geissler 2000, Mguni 2006, Copeland 2007).

\section{Plant materials}

Many plant species have been used by farmers across Sub-Saharan Africa to control termites (Logan et al. 1990, Nkunika 1998). Among the plant species mentioned frequently in the specific study sites and the literature, Euphorbia tirucalli ranks first. Farmers in Malawi and Zambia believe planting E. tirucalli in crop fields or applying its branches in planting holes deters termites (Orr and Ritchie 2004, Sileshi et al. 2008b). In Tanzania, the leaves and roots of E. tirucalli are soaked in water and the solution is sprayed to protect seedlings from termites (Logan et al. 1990). In Zambia, farmers apply crushed pods of Bobgunnia (Swartzia) madagascareinsis in planting holes (Nkunika 1998, Sileshi et al. 2008b). Extracts from leaves of Tephrosia vogelii are also used to protect tree seedlings in Malawi and Zambia (Nkunika 1998, Sileshi et al. 2008b). The limitation of plant materials is that farmers' recipes vary widely. The mechanism by which these concoctions reduce termite damage is as yet unclear. Most plant materials also break down rapidly in the soil and do not give prolonged protection from termite attack (Logan et al. 1990). In addition, the hazard they present to humans and the environment is often unknown. Therefore, greater care is required in their use. Rigorous toxicological, safety, and environmental evaluation is also needed for their wider application.

\section{Wood ash}

Wood ash has been widely mentioned as one of the control practices in eastern and southern Zambia (Nkunika 1998, Sileshi et al. 2008b) and Nigeria (Banjo et al. 2003). Logan et al. (1990) summarize reports about the use of wood ash for termite control. However, the mechanism by which ash provides protection against termites is unclear. Variations also exist on the effectiveness of ash (Nkunika 1998). This information gap demands better evaluation of wood ash against the most serious termites for the particular area.

\section{Protein- or sugar-based products}

In Uganda, farmers use dead animals, meat, and sugarcane husks to "poison" Macrotermes mounds (Sekamatte et al. 2001). Farmers in Tsangano district of Mozambique mentioned that they used leftover pork or beef to control termites (Sileshi et al. 2008b). Similarly, Nigerian farmers bury dead animals or fish viscera to reduce termite attack on crops (Logan et al. 1990). In South Africa, Riekert and van den Berg (2003) experimentally demonstrated significant reduction in termite damage to maize using fish meal. Until recently, the rationale behind this practice had not been clear (Logan et al. 1990). Sekamatte et al. (2001) demonstrated that the reduction in termite damage in plots that received fish meal is due to increased activity of ants. The protein-based baits resulted in greater ant nesting near maize plants and reduction in termite damage (Logan et al. 1990).

\section{Cow dung and urine}

Cow dung and urine have been used for termite control by farmers in the study areas (Malaret and Ngoru 1989, Nkunika 1998) as well as elsewhere (Banjo et al. 2003, Nwilene et al. 2008). In Machakos district of Kenya, farmers smear cow dung on posts to protect them from termite attack (Malaret and Ngoru 1989). In Monze district of Zambia, farmers used fresh cow dung to reduce termite damage to maize (Nkunika 1998). Similarly, farmers in southwestern Nigeria believe that goat and cow dung reduce termite damage (Banjo et al. 2003). Reduction in termite damage to rangeland using cow dung has been demonstrated in an experiment conducted in the "Cattle Corridor" of Uganda (Tenywa 2008). Further research should establish the effectiveness and the mechanism by which cow dung reduces termite damage to crops or trees.

\section{Intercropping}

According to farmers in parts of northern Uganda, maize intercropped with sorghum usually suffers less termite damage than pure stands. Farmers in this region regarded the sorghum plants as reservoirs of the predatory ants (Sekamatte et al. 2003). Intercropping maize with food legumes has been demonstrated to increase nesting of predatory ants and reduce termite attack on maize (Sekamatte et al. 2003). However, the impact of intercropping on termite damage depended largely on the legume species in the intercrop (Sekamatte et al. 2003, 
Fig. 3. Farmers' usually leave termitaria intact when cultivating crop fields. This figure shows live Macrotermes mounds left in a field ready for planting maize in Balaka district of southern Malawi.

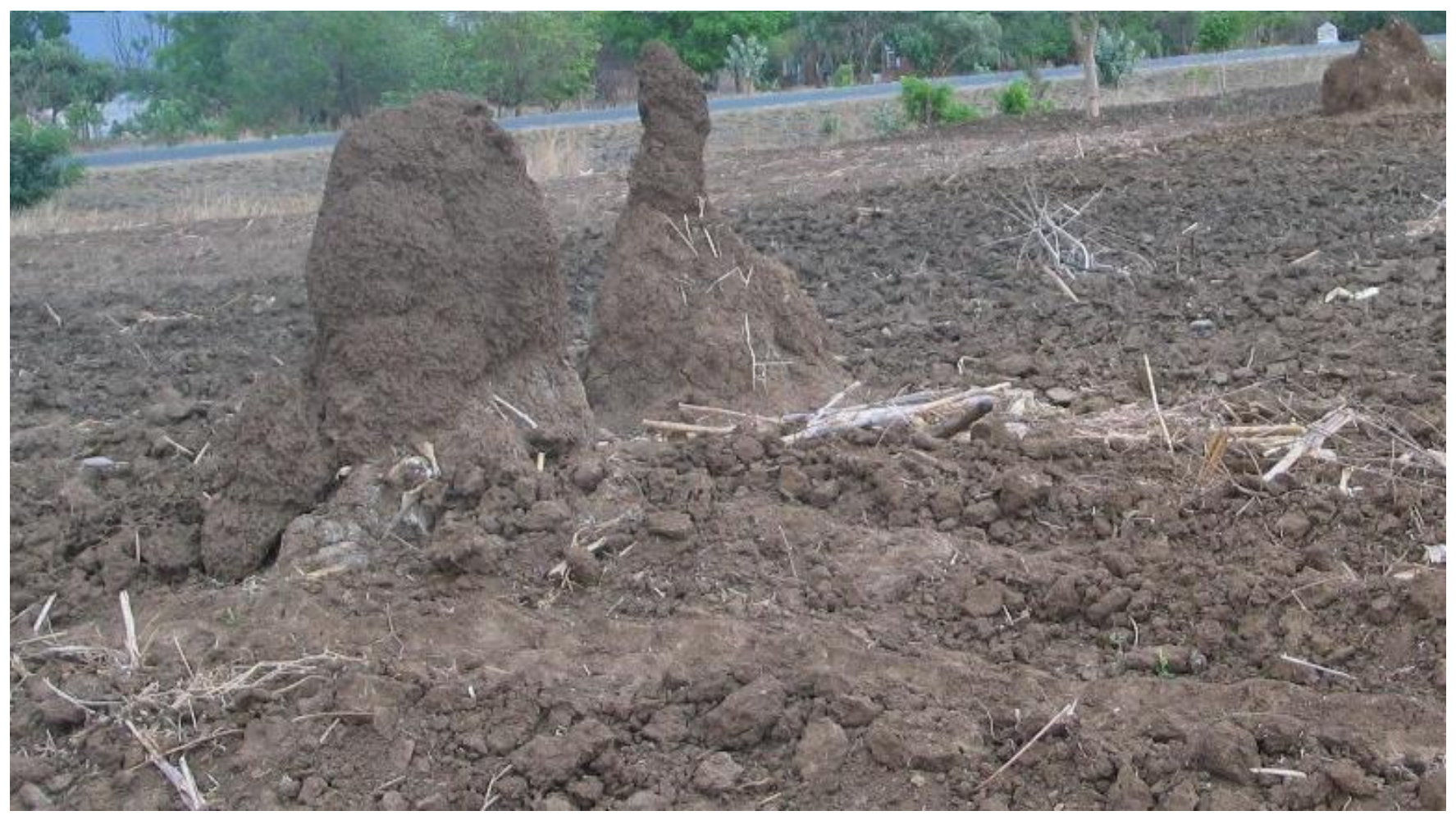

Sileshi et al. 2005). In Uganda, termite attack was lower in maize-soybean (Glycine max) than in maize-groundnut or maize-bean intercrops (Sekamatte et al. 2003). Similarly, in Zambia, some legume trees in agroforestry reduced termite damage to maize more than others (Sileshi et al. 2005). These differences could be attributed to variations in leaf litter, which serves as an alternative source of food for termites and the thick canopy in the intercrops that encouraged predation (Sekamatte et al. 2003, Sileshi et al. 2005).

\section{Weeding and tillage practices}

In Malawi and eastern Zambia, farmers avoided ridging the soil when weeding or reduced the weeding to a minimum in order to reduce termite damage on maize crops (Sileshi et al. 2008b). Tillage and weeding may have negative effects on termite activity because of the physical disruption of their feeding galleries, alteration of soil environment and food resources, and exposure to predators (Logan et al. 1990, Black and Okwakol 1997). However, conflicting reports exist on the effects of weeding on termite populations. This highlights the need for site-specific studies and recommendations.

\section{Potential Impacts of Disruptive Termite Control Practices}

Until recently, organochlorines, which are regarded as persistent organic pollutants (POPs) have been widely used for termite control (Logan et al. 1990, Langewald et al. 2003). With the banning of POPs, the search for alternative insecticides has increased. The most recent development in termite control involves fungicides targeted at the Termitomyces spp. (Rouland-Lefevre and Mora 2002). Such control practices are usually initiated on anecdotal information rather than on sound scientific inquiry 
into the biology of the local termite species or their true impact on crops or trees in Africa. None of the entomological literature in Africa provides any empirical data on the social, ecological, or economic risks and trade-offs of control practices. The impacts of chemical control on human welfare and the environment have also been largely ignored or perceived as localized problems. Termitaria are often the major source of apprehension and targets for application of pesticides and other control measures. Termite control using pesticides is likely to have negative impacts on human welfare and the environment in at least three ways. First, direct exposure of farm families to pesticides could occur because people who apply pesticides usually do not take precautions or wear protective clothing. Second, people who consume termites and mushrooms from treated termitaria could be exposed to pesticide residues. Third, children and women can be exposed to pesticides through consumption of soil from treated termitaria. In addition, termite control practices could pose risks to non-target organisms that inhabit termitaria or consume the soil. In the following sections we will briefly discuss the categories of organisms briefly.

Non-target termites: Many termite species that are not mound builders themselves make their nest within the fabric of existing termitaria (Coaton 1962, Glover 1967, Pomeroy et al. 1991). For example, in Zambia, Coaton (1962) found more than 20 different genera inhabiting mounds of other termites (on average, 3.4 genera per mound). Some of these species, which are harmless, may be killed by control practices targeted at the termitaria.

Symbionts: Termite symbioses are characterized by obligate nutritional mutualisms between the insect host and various micro-organisms including bacteria, protozoa, and fungi (Bignell 2000). The gut of termites is a rich reservoir of novel microorganisms (Mackenzie et al. 2007) and biochemical pathways that may even provide the means to produce green biofuels from wood (Rubin 2008). Microbial communities that inhabit termite nests are also of great genetic and functional diversity that could be used for phytoremediation (Duponnois et al. 2006). Among the fungi, members of the genus Termitomyces live in a mutualistic association with the Macrotermitinae (Aanen and Eggleton 2005) and produce edible mushrooms. Termite control using fungicides targeted at the Termitomyces spp. (Rouland-Lefevre and Mora 2002) may have negative impacts on the ecosystem services of termites, including production of edible mushrooms.
Termitophilous and termitolestic species: Termitaria also provide habitat for a variety of termitophilous animals, which live in termite nests and steal or scavenge food from termites. These include obligatory inquilines of Insecta, Isopoda, Collembola, Thysanura, and Psocoptera (Glover 1967, Kistner 1990, Pomeroy et al. 1991). Termitolestic species live in or near the nest and regularly prey on the termites (de Visser et al. 2008). This includes ants, spiders, centipedes, and assassin bugs (Pomeroy et al. 1991). Many of these invertebrates are poorly studied and their community structure and function not known.

Vertebrates that feed and nest in termitaria: Termites form the major dietary component of many animals, including invertebrates and vertebrates. For some animals, such as the aardvark, termites are the main food (Pomeroy et al. 1991, Peveling et al. 2003). Termites are also the most nutritionally important insects in the diet of chimpanzees and gorillas (Tutin and Fernandez 1983, Cipolleta et al. 2007, Deblauwe and Jenssens 2007). During swarming, termites form a major source of food for many amphibians, reptiles, birds, and mammals (Dial and Vaughan 1987). In addition, many animals including birds, reptiles (e.g., geckoes, lizards, and snakes), and mammals nest in termitaria (Glover 1967, Pomeroy et al. 1991). For example, barbets (Trachyphonus spp.) preferentially nest in burrows in the wall of termitaria (Pomeroy et al. 1991). The Nile monitor (Varanus niloticus) buries its eggs in termitaria for incubation (Bennett 1995). Mongooses are largely dependent on termitaria for safe den sites (Rasa 1985). Among the modern insecticides used for termite control, carbamates are regarded as not toxic to mammals. However, they are extremely toxic to birds. Therefore, use of carbamates can kill birds that have eaten poisoned termites or nest in termitaria. Poisoning the termitaria is also likely to have negative impacts on the other organisms.

Animals that ingest soil: Termitaria also serve as salt licks for both domestic and wild animals. For example, elephants (Loxodonta africana) are known to excavate termitaria and eat the soil to satisfy their need for micronutrients such as iodine, cobalt, and selenium (Milewski and Diamond 2000). Consumption of soil from termitaria is also very common among primates (Klein et al. 2008).

Herbivorous animals: Termitaria usually act as grazing and browsing hotspots for herbivores (Holdo and McDowell 2004, Loveridge and Moe 
2004, Mobæk et al. 2005). In Uganda, ungulates grazed preferentially on termitaria compared with the adjacent savannah (Mobæk et al. 2005). In Zimbabwe, trees growing on termitaria were subjected to more intense feeding by elephants and rhinoceros (Diceros bicornis, Ceratotherium simum) than trees in the surrounding vegetation matrix (Holdo and McDowell 2004, Loveridge and Moe 2004). Therefore, indiscriminate use of pesticides on termitaria may put the health of animals that either graze or browse the vegetation or consume the soil.

\section{CONCLUSION}

The review of the general literature and specific studies leads to the conclusion that local communities have comprehensive indigenous knowledge of termite ecology and taxonomy and apply various indigenous control practices. Farmer innovation was evident in the diversity of indigenous termite control practices. Farmers have a more tolerant attitude toward termites and termite mounds than do researchers. It is not surprising that traditional agriculture has coexisted with termites in Africa.

The review above indicates that termite control practices can have negative impacts on human welfare and the environment in a number of ways. Therefore, more balanced termite management practices are needed to ensure human welfare and maintenance of the ecosystem services provided by termites. Farmers' indigenous knowledge may help in improving the existing practices or searching for environmentally friendly and socially acceptable management approaches. Farmers' indigenous practices depend on intimate knowledge of the local situation. Unfortunately, indigenous practices have been dismissed by some researchers as unsatisfactory without adequate research. This is because the performance of indigenous practices is often judged against insecticidal control, which often gives an immediate result. Instead of dismissing such practices as ineffective, their rationale and shortcomings need to be identified to generate contextual and site-specific knowledge. In this way, limitations of indigenous practices can be removed and solutions with local relevance may be found. This emphasizes the point that ethnoecological knowledge is best employed as a complement to, rather than a substitute for, scientific knowledge. There are many ways in which indigenous practices may be fine tuned if farmers and scientists work together and learn from each other. Toward that end, we recommend a farmertargeted participatory research approach to build coherent principles for termite management in Africa.

Responses to this article can be read online at: http://www.ecologyandsociety.org/voll4/iss 1/art48/ responses/

\section{Acknowledgments:}

The field work by the first three authors was supported by the Sustainable Agriculture Initiative of the Council for the Development of Social Science Research in Africa (CODESRIA) and International Foundation for Science (IFS). Financial supportfor part of the field work and manuscript preparation also came from the United States Agency for International Development (USAID), Canadian International Development Agency (CIDA), Swedish International Development Agency (Sida), and Irish Aid through the World Agroforestry Centre (ICRAF).

\section{LITERATURE CITED}

Aanen, D. K., and P. Eggleton. 2005. Fungusgrowing termites originated in African rain forest. Current Biology 15:851-855.

Adamou, I., N. J. Pierre, P. Pogenet, B. Tchimbi, and G. Gonlaina. 2007. Soil degradation in the Sudano-Guinea savannas of Mbe, Cameroon: farmers' perception, indicators and soil fertility management strategies. Research Journal of Agriculture and Biological Sciences 3:907-916.

Andrianjaka, Z., R. Bally, M. Lepage, J. Thioulouse, G. Comte, M. Kisa, and R. Duponnois. 2007. Biological control of Striga hermonthica by Cubitermes termite mound powder amendment in sorghum culture. Applied Soil Ecology 37:175-183.

Banjo, A. D., O. A. Lawal, O. E. Fapojuwo, and E. A. Songonuga. 2003. Farmers' knowledge and perception of horticultural insect pest problems in 
southwestern Nigeria. African Journal of Biotechnology 2:434-437.

Bellon, M. R., P. Gambara, T. Gatsi, T. E. Machemedze, O. Maminimini, and S. R. Waddington. 1999. Farmers' taxonomies as a participatory diagnostic tool: soil fertility management in Chihota, Zimbabwe. CIMMYT Economics Working Paper No.13. Centro Internacional de Mejoramiento de Maíz y Trigo (CIMMYT), El Batan, Texcoco, Mexico.

Bennett, D. 1995. A little book of monitor lizards. Viper Press, Glossop, UK.

Berkes, F. 2008. Sacred ecology: traditional ecological knowledge and resources management. Second edition. Routledge, New York, New York, USA.

Bignell, D. E. 2000. Introduction to symbiosis. Pages 189-208 in T. Abe, D. E. Bignell, and M. Higashi, editors. Termites: evolution, sociality, symbioses, ecology. Kluwer Academic Publishers, Dordrecht, The Netherlands.

Black, H. I. J., and M. J. N. Okwakol. 1997. Agricultural intensification, soil biodiversity and agroecosystem function in the tropics: the role of termites. Applied Soil Ecology 6(1):37-53.

Brossard, M., D. López-Hernández, M. Lepage, and J.-C. Leprun. 2007. Nutrient storage in soils and nests of mound-building Trinervitermes termites in Central Burkina Faso: consequences for soil fertility. Biology and Fertility of Soils 43:437447.

Brouwer, J., L. K. Fussell, and L. Hermann. 1993. Soil and crop growth microvariability in the West African semiarid tropics - a possible risk-reducing factor for subsistence farmers. Agriculture, Ecosystem and Environment 45:229-238.

Cadet, P., L. Guichaoua, and V. W. Spaull. 2004. Nematodes, bacterial activity, soil characteristics and plant growth associated with termitaria in a sugarcane field in South Africa. Applied Soil Ecology 25:193-206.

Chikuvire, T. J., S. Mpepereki, and R. Foti. 2007. Soil fertility variability in sandy soils and implications for nutrient management by smallholder farmers in Zimbabwe. Journal of Sustainable Agriculture 30:69-87.
Cipolleta, C., Spagnoletti, N., A. Todd, M. M. Robbins, H. Cohen, and S. Pacyna. 2007. Termite feeding by Gorilla gorilla gorilla at Bai Hokou, Central African Republic. International Journal of Primatology 28:457-476.

Coaton, W. G. H. 1962. The origin and development of massive vegetated termite hills in Northern Rhodesia. African Wild Life 16:159-166.

Copeland, V. N. E. 2007. Anthills touch the sky: Sembène's topographical aesthetic. Pages 10-24 in M. Compan and K. Pieprzak, editors. Land and landscape in francographic literature: remapping uncertain territories. Cambridge Scholars Publishing, Newcastle, UK.

Darlington, J. P. E. C., R. B. Benson, C. E. Cook, and G. Walker. 2008. Resolving relationships in some African fungus-growing termites (Termitidae, Macrotermitinae) using molecular phylogeny, morphology, and field parameters. Insectes Sociaux 55:256-265.

Deblauwe, I., and G. P. J. Janssens. 2007. New insights in insect prey choice by chimpanzees and gorillas in southeast Cameroon: the role of nutritional value. American Journal of Physical Anthropology 135:42-55.

de Visser, S. N., B. P. Freymann, and H. Schnyder. 2008. Trophic interactions among invertebrates in termitaria in the African savanna: a stable isotope approach. Ecological Entomology 33:758-764.

Dial, K.P., and T.A. Vaughan. 1987. Opportunistic predation on alate termites in Kenya. Biotropica 19:185-187.

Duponnois R., M. Kisa, K. Assigbetse, Y. Prin, J. Thioulouse, M. Issartel, P. Moulin, and M. Lepage. 2006. Fluorescent pseudomonads occuring in Macrotermes subhyalinus mound structures decrease Cd toxicity and improve its accumulation in sorghum plants. Science of the Total Environment 370:391-400.

Eggleton, P. 2000. Global patterns of termite diversity. Pages 25-51 in T. Abe, D. E. Bignell, and M. Higashi, editors. Termites: evolution, sociality, symbioses, ecology. Kluwer Academic Publishers, Dordrecht, The Netherlands.

Eggleton, P., D. E. Bignell, S. Hauser, L. Dibog, L. Norgrove, and B. Madong. 2002. Termite 
diversity across an anthropogenic gradient in the humid forest zone of West Africa. Agriculture, Ecosystems and Environment 90:189-202.

Ettema, C.H. 1994. Indigenous soil classifications: what is their structure and function, and how do they compare to scientific soil classifications? University of Georgia, Athens, Georgia, USA.

Fauchereau, N., S. Trzaska, M. Rouault, and Y. Richard. 2003. Rainfall variability in southern Africa during the $20^{\text {th }}$ century in the global warming context. Natural Hazards 29:139-154.

Geissler, P. W. 2000. The significance of eartheating: social and cultural aspects of geophagy among Luo children. Africa 70:653-682.

Glover, P. E. 1967. Further notes on some termites of northern Somalia. East African Wildlife Journal 5:121-132.

Harris, D., G. J. Fry, and S. T. Miller. 1994. Microtopography and agriculture in semi-arid Botswana. 2. Moisture availability, fertility and crop performance. Agricultural Water Management 26:133-148.

Holdo, R. M., and L. R. McDowell. 2004. Termite mounds as nutrient-rich food patches for elephants. Biotropica 36:231-239.

Holt, J. A., and M. Lepage. 2000. Termites and soil properties. Pages 389-407 in T. Abe, D. E. Bignell, and M. Higashi, editors. Termites: evolution, sociality, symbioses, ecology. Kluwer Academic Publishers, Dordrecht, The Netherlands.

Hunter, J. M. 1973. Geophagy in Africa and in the United States: a culture-nutrition hypothesis Geographical Review 63:170-195.

Jiru,D. 2006. Trees with insecticidal properties and indigenous knowledge base with coping mechanisms against pests. Pages 88-91 in E. Bekele, F. Azerefegn, and T. Abate, editors. Facilitating the implementation and adaptation of integrated pest management (IPM) in Ethiopia. Drylands Coordination Group, Addis Ababa, Ethiopia.

Jones, J.A. 1990. Termites, soil fertility and carbon cycling in dry tropical Africa: a hypothesis. Journal of Tropical Ecology 6:291-305.
Kabasa J. D., D. Olila, D. Okethwangu, P. K. T. Munishi, and I. Kisovi. 2006. Nutritive and nutriceutic potential of indigenous Bubaala mushrooms Termitomyces microcarpus from the Lake Victoria basin. African Journal of Animal and Biomedical Sciences 1:92-96.

Kistner, D. H. 1990. The integration of foreign insects into termite societies or why do termites tolerate foreign insects in their societies. Sociobiology 17:191-215.

Klein, N., F. Fröhlich, and S. Krief. 2008. Geophagy: soil consumption enhances the bioactivities of plants eaten by chimpanzees. Naturwissenschaften 95:325-331.

Knudsen, J. W. 2002. Akula udongo (earth eating habit): a social and cultural practice among Chagga women on the slopes of Mount Kilimanjaro. African Journal of Indigenous Knowledge Systems 1:19-26.

Langewald, J., J. D. Mitchell, N. K. Maniania, and C. Kooyman. 2003. Microbial control of termites in Africa. Pages 227-242 in P. Neuenschwander, C. Borgameister, and J. Langewald, editors. Biological control in IPM systems in Africa. CAB International, Wallingford, UK.

Lepage, M., L. Abbadie, and A., Mariotti. 1993. Food habits of sympatric termite species (Isoptera, Macrotermitinae) as determined by stable carbon isotope analysis in a Guinean savanna (Lamto, Cote d'Ivoire). Journal of Tropical Ecology 9:303-311.

Logan, J. W. M. 1992. Termites (Isoptera): a pest or resource for small scale farmers in Africa. Tropical Science 32:71-79.

Logan, J. W. M., R. H. Cowie, and T. G. Wood. 1990. Termite (Isoptera) control in agriculture and forestry by nonchemical methods: a review. Bulletin of Entomological Research 80:309-330.

Loveridge, J. P., and S. R. Moe. 2004. Termitaria as browsing hotspots for African megaherbivores in miombo woodland. Journal of Tropical Ecology 20:337-343.

Luoba, A. I., W. P. Geissler, B. Estambale, J. H. Ouma, P. Magnussen, D. Alusala, R. Ayah, D. Mwaniki, and H. Friis. 2004. Geophagy among pregnant and lactating women in Bondo District, 
western Kenya. Transactions of the Royal Society of Tropical Medicine and Hygiene 98:734-741.

Mackenzie, L. M., A. T. Muigai, E. O. Osir, W. Lwande, M. Keller, G. Toledo, and H. I. Boga. 2007. Bacterial diversity in the intestinal tract of the fungus cultivating termite Macrotermes michaelseni (Sjöstedt). African Journal of Biotechnology 6:658667.

Mando, A., L. Brussard, and L. Stroosnijder. 1999. Termite- and mulch-mediated rehabilitation of vegetation on crusted soil in West Africa. Restoration Ecology 7:33-41.

Malaisse, F. 1978. High termitaria. Pages 12791300 in M. J. A. Werger, editor. Biogeography and ecology of Southern Africa. Dr. W. Junk b.v., The Hague, The Netherlands.

Malaret, L., and F. N. Ngoru. 1989. Ethnoecology: a tool for community based pest management farmer knowledge of termites in Machakos district, Kenya. Sociobiology 15:197211.

Masanori, T., and A. Tooru. 2004. Soil nutrient loss caused by intensive land use and the retention of nutrients inside termite mounds in Niger, Africa. Japanese Journal of Ecology 54:117-124.

Mguni, S. 2006. Iconography of termites' nests and termites: symbolic nuances of formlings in southern African San rock art. Cambridge Archaeological Journal 16:53-71.

Mielke, H. W., and P. W. Mielke. 1982. Termite mounds and chitemene agriculture: a statistical analysis of their association in southwestern Tanzania. Journal of Biogeography 9:499-504.

Milewski, A. V., and R. E. Diamond. 2000. Why are very large herbivores absent from Australia? A new theory of micronutrients. Journal of Biogeography 27:957-978.

Mitchell, J. D. 2002. Termites as pests of crops, forestry, rangeland and structures in southern Africa and their control. Sociobiology 40:47-69.

Mobæk, R., A. K. Narmo, and S. R. Moe. 2005. Termitaria are focal feeding sites for large ungulates in Lake Mburo National Park, Uganda. Journal of Zoology 267:97-102.
Nchito, M., P. W. Geissler, L. Mubila, H. Friis, and A. Olsen. 2004. Effects of iron and multimicronutrient supplementation on geophagy: a two-by-two factorial study among Zambian school children in Lusaka. Transactions of the Royal Society of Tropical Medicine and Hygiene 98:218227.

Nkunika, P. O. Y. 1998. Termite survey, identification, damage and control in southern province. Land Management and Conservation Farming, Soil Conservation and Agroforestry Extension Report, Lusaka, Zambia.

Nwilene, F. E., T. A. Agunbiade, M. A. Togola, O. Youm, O. Ajayi, S. O. Oikeh, S. Ofodile, and O. O. Falola. 2008. Efficacy of traditional practices and botanicals for the control of termites on rice at Ikenne, southwest Nigeria. International Journal of Tropical Insect Science 28:37-44.

Nyamapfene, K. W. 1986. The use of termite mounds in Zimbabwe peasant agriculture. Tropical Agriculture (Trinidad) 63:152-192.

Nyeko N., and F. M. Olubayo. 2005. Participatory assessment of farmers' experiences of termite problems in agroforestry in Tororo district, Uganda. Agricultural Research and Extension Network Paper No. 143, Overseas Development Institute, London, UK.

Okwakol, M. J. N., and M. B. Sekamatte. 2007. Soil macrofauna research in ecosystems in Uganda. African Journal of Ecology 45:2-8.

Opige, M., E. Kateyo, J. D. Kabasa, and D. Olila. 2006. Comparative chemical composition of two indigenous edible mushrooms from the Teso region of Uganda (Termitomyces microcarpus [Eswei] and Termitomyces giganticus [Imruk]). African Journal of Animal and Biomedical Sciences 1:1-6.

Orr, A., and J. M. Ritchie. 2004. Learning from failure: smallholder farming systems and IPM in Malawi. Agricultural Systems 79:31-5.

Oso, B.A. 1975. Mushrooms and the Yoruba people of Nigeria. Mycologia 67:311-319.

Peveling, R., A. N. McWilliam, P. Nagel, H. R. Rasolomanana, L. Rakotomianina, A. Ravoninjatovo, C. F. Dewhurst, G. Gibson, S. Rafanomezana, and C. C. D. Tingle. 2003. Impact of locust control 
on harvester termites and endemic vertebrate predators in Madagascar. Journal of Applied Ecology 40:729-741.

Pomeroy, D. E. 1978. The abundance of large termite mounds in Uganda in relation to their environment. Journal of Applied Ecology 15:51-63.

Pomeroy, D. E., R. K. Bagine, and J. P. E. C. Darlington. 1991. Fungus-growing termites in East African Savannas. Pages 41-50 in F. I. B. Kayanja and E. L. Edroma, editors. African wild research and management. International Council of Scientific Unions, Paris, France.

Rasa, A. 1985. Mongoose watch. John Murray, London, UK.

Riekert, H. F., and J. van den Berg. 2003. Evaluation of chemical control measures for termites in maize. South African Journal of Plant and Soil 20:1-5.

Rouland-Lefevre, C., and P. Mora. 2002. Control of Ancistrotermes guineensis Silvestri (Termitidae: Macrotermitinae), a pest of sugarcane in Chad. International Journal of Pest Management 48:8186.

Rowland, M. J. 2002. Geophagy: an assessment of implications for the development of Australian indigenous plant processing technologies. Australian Aboriginal Studies 2002:51-66.

Rubin, E. M. 2008. Genomics of cellulosic biofuels. Nature 454:841-845.

Saathoff, E., A. Olsen, J. D. Kvalsvig, and P. W. Geissler. 2002. Geophagy and its association with geohelminth infection in rural schoolchildren from northern KwaZulu-Natal, South Africa. Transactions of the Royal Society of Tropical Medicine and Hygiene 96:485-490.

Sekamatte, M. B., and M. J. N. Okwakol. 2007. The present knowledge on soil pests and pathogens in Uganda. African Journal of Ecology (Supplement) 45:9-19.

Sekamatte M. B., M. Ogenga-Latigo, and A. Russell-Smith. 2001. The potential of protein- and sugar-based baits to enhance predatory ant activity and reduce termite damage to maize in Uganda. Crop Protection 20:653-662.
Sekamatte M. B., M. Ogenga-Latigo, and A. Russell-Smith. 2003. Effect of maize-legume intercrops on termite damage to maize, activity of predatory ants and maize yield in Uganda. Crop Protection 22:87-93.

Siame, J. A. 2005. Termite mounds as fertilizer. LEISA India 7(2):27. [online] URL: http://www.lei sa.info/index.php?url=magazine-details.tpl\&p[ id] $=81274$

Sileshi G., P. L. Mafongoya, F. Kwesiga, and P. Nkunika. 2005. Termite damage to maize grown in agroforestry systems, traditional fallows and monoculture on nitrogen-limited soils in eastern Zambia. Agriculture and Forest Entomology 7:6169.

Sileshi, G., F. K. Akinnifesi, O. C. Ajayi, S. Chakeredza, S. Mng'omba, and B. I. Nyoka. 2008a. Towards sustainable management of soil biodiversity in agricultural landscapes in Africa. Biodiversity 9:64-67.

Sileshi, G., E. Kuntashula, P. Matakala, and P. O. Nkunika. 2008b. Farmers' perceptions of pests and pest management practices in agroforestry in Malawi, Mozambique and Zambia. Agroforestry Systems 72:87-101.

Steinke, T. D., and L. O. Nell. 1989. Some effects of termitaria on veld in the eastern Cape. Tydskrif Weidingsveren 6:152-155.

Tenywa, G. 2008. Thousands homeless as termites turn Nakasongola into a desert. The New Vision, 24 June 2008. [online] URL: http://www.newvision.co. ug/D/9/36/635585?highlight\&q=termite.

Tutin, C. E. G., and M. Fernandez. 1983. Gorillas feeding on termites in Gabon, West Africa. Journal of Mammalogy 64:530-531.

United Nations Environment Programme (UNEP)/GRID-Arendal. 2002. Aridity zones. UNEP/GRID-Arendal maps and graphics library, Arendal, Norway. [online] URL: http://maps.grida. no/go/graphic/aridity zones.

United Nations University (UNU). 1998. Land degradation and rural poverty in Africa: examining the evidence. United Nations University/Institute for Natural Resources Assessment Lecture Series 1. UNU/INRA, Accra, Ghana. 
Watson, J. P. 1977. The use of mounds of the termite Macrotermes falciger (Gerrstäcker) as a soil amendment. Journal of Soil Science 28:664-672.

Wiley, A. S., and S. H. Katz. 1998. Geophagy in pregnancy: a test of a hypothesis. Current Anthropology 39:532-545.

Wood. T. G., R. A. Johnson, and C. E. Ohiagu. 1980. Termite damage and crop loss studies in Nigeria-a review of termite (Isoptera) damage to maize and estimation of damage, loss in yield and termite (Microtermes) abundance at Mokwa. Tropical Pest Management 26:241-253.

Yongabi, K., M.Agho, and D. Martinez-Carrera. 2004. Ethnomycological studies on wild mushrooms in Cameroon, Central Africa. Micologia Applicada International 16:34-36. 